\title{
Human rights in the courts of Northern Ireland 2009-10
}

\author{
BRICE DICKSON \\ Queen's University Belfast \\ Terence McCleave \\ Barrister, Northern Ireland*
}

\begin{abstract}
T $\mathrm{t}$ is now over a decade since the Human Rights Act 1998 came into force in Northern Ireland, thereby effectively making European Convention rights (the ECHR) part of domestic law. During that time innumerable cases have come before the courts raising not only Convention rights but also human rights deriving from other sources, including the common law. This article presents a flavour of current judicial approaches to human rights arguments in Northern Ireland by surveying all relevant decisions of the courts of Northern Ireland during the 2009-10 legal year. ${ }^{1}$ It aims to convey a sense of not just the variety of claims dealt with but also the depth of treatment to which they were subjected by the judges. Northern Ireland is clearly a jurisdiction where human rights jurisprudence is a very live topic, one which is constantly developing and which requires lawyers and commentators to be always on the alert. $^{2}$
\end{abstract}

\section{The right to life}

The extent to which the right to life is protected by law in Northern Ireland was at issue in no fewer than six cases, including one decided by the Court of Appeal. Three involved troubles-related deaths, two required examination of the law on threats, and one concerned the law on abortion.

Two of the troubles-related cases involved inquests. In Re McCanghey and Quinn's Application, the applicants challenged the rulings by the House of Lords in Re McKerr ${ }^{3}$ that the Human Rights Act had no retrospective application and that the substantive and procedural aspects of Article 2 were not severable. They relied on the recent judgment of

* Brice Dickson is Professor of International and Comparative Law, and Director of the Human Rights Centre, in the School of Law at Queen's University Belfast; Terence McCleave is a barrister in Northern Ireland. The authors are very grateful to Dr Gordon Anthony for comments he made on a draft of this article. Any remaining errors are theirs alone.

1 I.e. from September 2009 to August 2010. The survey does not include tribunal decisions.

2 For other relevant surveys see R McQuigg, "A 'very limited' effect or a 'seismic' impact? A study of the impact of the Human Rights Act 1998 on the courts of Northern Ireland” (2010) Public Law 551; B Dickson, "Northern Ireland", in A Lester, D Pannick and J Herberg (eds), Human Rights Law and Practice 3rd edn (London: LexisNexis 2009), ch. 6; B Dickson, "The impact of the Human Rights Act in Northern Ireland" in J Morison, K McEvoy and G Anthony (eds), Judges, Transition and Human Rights (Oxford: OUP 2007), ch. 11.

3 [2004] 1 WLR 807. 
the Grand Chamber of the European Court of Human Rights (ECtHR) in Silih v Slovenia, ${ }^{4}$ where the Court said:

The procedural obligation to carry out an effective investigation under Article 2 has evolved into a separate and autonomous duty. Although it is triggered by the acts concerning the substantive aspects of Article 2 it can give rise to a finding of a separate and independent "interference". . In this sense it can be considered to be a detachable obligation arising out of Article 2 capable of binding the State even when the death took place before the critical date. ${ }^{5}$

The Grand Chamber's reasoning appears to contradict the House of Lords' finding in McKerr and the applicants argued that it should be preferred. Both Weatherup $\mathrm{J}^{6}$ and, on appeal, the Court of Appeal ${ }^{7}$ adopted the approach laid down by the Law Lords in Kay $\mathrm{v}$ Lambeth $L B C$, where they held that, unless there are exceptional circumstances, lower courts should follow the domestic precedent and then grant leave to appeal. ${ }^{8}$ The Court of Appeal was particularly wary of the applicability of Silib to the domestic sphere, because the United Kingdom had not been a party to the case, but it did note that it was "arguable, given the constructive dialogue engaged in by the highest court in the United Kingdom with the ECtHR, that the Supreme Court may choose to extend Silih to our domestic law". 9 The Court of Appeal therefore granted leave to apply for judicial review on Article 2 grounds but, when it then proceeded to consider the judicial review, it held against the applicants on the merits. Shortly afterwards, however, it granted leave for the applicants to appeal to the Supreme Court, a bold move in view of the Supreme Court's growing desire to have complete control over its own docket. ${ }^{10}$ The case will provide a further opportunity for that court to clarify how it views the function of the ECtHR with regard to Convention rights in a common law setting, a matter that has already elicited strong views from senior British judges. ${ }^{11}$ The Attorney General for Northern Ireland, John Larkin QC, who will be an intervener in the Supreme Court case, has already intimated that he considers Silib to have been wrongly decided. ${ }^{12}$

4 (2009) 49 EHRR 37.

5 Ibid. para. 159 (emphasis added).

6 [2009] NIQB 77.

7 [2010] NICA 13.

8 [2006] 2 AC 465, paras 42-5 (per Lord Bingham). See too Rush v Chief Constable of the Police Service of Northern Ireland [2010] NIMaster 6, the third of the year's cases involving troubles-related deaths, where the applicant argued that the police and government had failed to take reasonable steps to protect the life of his wife (who was killed in the bombing of Omagh in August 1998) and to properly investigate her death. The Master struck out the claim after the parties accepted that in light of McKerr no challenge to a pre-2000 death could be sustained on the basis of Article 2.

9 [2010] NICA 13, para. 16 (per Deeny J).

10 Adverse comments about the readiness of the Court of Appeal of Northern Ireland to grant leave to appeal were made by the House of Lords in McE v Prison Service of Northern Ireland [2009] UKHL 15, [2009] 2 WLR 782, para. 77 (per Lord Carswell).

11 See, e.g., the Supreme Court's ruling in R v Horncastle [2010] 2 WLR 47; Lord Hoffmann's comments in Secretary of State for the Home Department v AF (No 3) [2009] 3 WLR 74, para. 70; Lord Hoffmann's Judicial Studies Board Annual Lecture, "The universality of human rights", 19 March 2009, available at www.jsboard.co.uk/aboutus/annuallectures.htm; and Arden LJ's "Is the Convention ours?", an intervention made during an event to mark the start of the legal year in Strasbourg, 2010, available at www.echr.coe.int/NR/rdonlyres/9D841412-0F36-411B-ABEC-3517B0364A44/0/20100129_Speech_ Lady_Arden_Seminar.pdf.

12 Speech at the Annual Conference of the Northern Ireland Human Rights Commission, Belfast, 16 September 2010 (on file with the authors). 
The second decision on inquests was Re Chief Constable of the PSNI's Application. ${ }^{13}$ The Senior Coroner had suggested that he may, following the ruling by the House of Lords in Jordan $\mathrm{v}$ Lord Chancellor, ${ }^{14}$ re-open several inquests into the deaths of individuals killed during the troubles in Northern Ireland. He indicated that his final decision would depend on whether he was able to get access to the Stalker/Sampson reports, which are reports into allegations that the security forces in Northern Ireland conducted a "shoot-to-kill policy" in the 1980s. He said it was his intention to furnish "properly interested persons", such as the bereaved families, with copies of the reports so that they could participate effectively in the inquest proceedings. ${ }^{15}$ The Chief Constable argued that the coroner had failed to consider the Article 2 rights of third parties who may be identified in the reports, but in rejecting the challenge Gillen J noted that "the Coroner must be invested with a wideranging discretion as to how he conducts his inquiry and a greater flexibility of approach than might be appropriate in other civil or criminal proceedings". ${ }^{16} \mathrm{He}$ added that the coroner had indicated his "readiness to accept redacted copies of the reports for dissemination to enable the applicant to make a public interest immunity request if the Coroner considers that those redacted areas are relevant to his inquiry". ${ }^{17}$ For that reason, Gillen J held that here the Article 2 rights of third parties were "amply" protected. ${ }^{18}$

The year's two cases on threats each gave the judges an opportunity to affirm that the Article 2-based right to protection of life arises only if there is a "real and immediate risk" to the claimant's life. In Re JR 20's (Firearms Certificate) Application, ${ }^{19}$ the applicant sought to challenge a decision by the Secretary of State to refuse his appeal against the revocation of his firearms certificate. He had previously been allowed to hold a firearm as a personal protection weapon but the police now believed that he had been involved with a proscribed organisation and in criminal activity. The applicant asserted that the revocation of his certificate violated his Article 2 right because the police had informed him on several occasions that threats had been made against his life. Weatherup J confirmed that Article 2 imposes a positive obligation on the state only where authorities "knew or ought to have known ... of the existence of a real and immediate risk to the life of an identified individual" 20 and he relied on $\mathrm{Re}$ Officer $L^{21}$ to assert that the threshold for measuring that risk was high. ${ }^{22}$ Here the available evidence did not establish such a risk. The judge added, obiter, that even if the threshold had been crossed it did not necessarily follow that the applicant should be issued with a personal protection weapon. Moreover, the applicant's private interest in disclosure of the information detailing his apparent association with a proscribed organisation had to yield to the public interest in protecting the source of that information. ${ }^{23}$ This is reconcilable with the earlier ruling by the House of Lords (not cited in $\mathrm{Re} J \mathrm{R} 20$ 's Application) that a person who is the subject of a control order has to be given sufficient information about the allegations made against him or her to allow effective

13 [2010] NIQB 66.

14 [2007] 2 AC 226.

15 [2010] NIQB 66, para. 6 (per Gillen J).

16 Ibid. para. 25.

17 Ibid. para. 46.

18 Ibid.

19 [2010] NIQB 11.

20 Osman v United Kingdom (2000) 29 EHRR 245, para. 116.

21 [2007] 1 WLR 2135.

22 Ibid. para. 20.

23 Ibid. para. 31. 
instructions to be given to a legal representative. ${ }^{24}$ What was at stake in that case was a person's liberty, or at least freedom of movement, while what was at stake in $R e J R$ 20's Application was only a person's right to possess a firearm: the former deserves to be told much more than the latter about the reasons for the administrative decision in question.

The second case on threats was $\mathrm{R} e \mathrm{R} A$ 's Application, ${ }^{25}$ where the applicant sought to quash a ruling by a District Judge that a reporting restriction, imposed under the Contempt of Court Act 1981, ${ }^{26}$ could not be extended. He wanted the court to consider, when assessing whether a restriction was "necessary for avoiding a substantial risk of prejudice to the administration of justice", the existence of a real and immediate risk to his life. The Divisional Court noted that pre- and post-Human Rights Act authorities indicated that the issue of risk should be excluded from the judges' examination as to whether a reporting restriction should be made, ${ }^{27}$ since the main issue was the effect of the restriction on the administration of justice when viewed in light of the fundamental principle of open justice. ${ }^{28}$ Nevertheless, the court also held that judges, as public authorities, were obliged to consider the applicant's Convention rights ${ }^{29}$ and it cited with approval the comments of Lord Rodger in In re Guardian News and Media Ltd, where he indicated that a court could help protect a claimant by, for example, replacing his or her name with a letter or number. ${ }^{30}$

The nexus, if any, between Article 2 and abortion has long been controversial and it was again at issue in $\mathrm{Re}$ Society for the Protection of Unborn Children's Application. ${ }^{31}$ The society was challenging guidance issued by a government department, which sought to clarify the law relating to abortion in Northern Ireland. It argued that the guidance failed to make reference to the interests of the unborn child, citing not just Article 2 of the ECHR but also Article 3 of the Universal Declaration of Human Rights (UDHR), the preamble to the UN Convention on the Rights of the Child (UNCRC), and the International Covenant on Civil and Political Rights (ICCPR). Girvan LJ was quick to confirm that the UDHR, the UNCRC and the ICCPR are unincorporated treaties and "cannot confer on the unborn child rights which do not exist under domestic law". ${ }^{32}$ He also recognised that, in cases such as $V o$ v France 33 and Paton v UK, ${ }^{34}$ the ECtHR "has not construed Article 2 as giving rise to rights vested in the unborn foetus" 35 but he noted that a case against Ireland was pending

24 Secretary of State for the Home Dept v AF (No 3) [2009] 3 WLR 74.

25 [2010] NIQB 27.

26 S. $4(2)$.

27 The court cited Re Belfast Telegraph Newspapers Ltd Application [1997] NI 309 and In re Times Newspapers Ltd and another [2009] 1 WLR 1015.

28 The court recognised that the principle of open justice was enshrined in both Article 6 of the ECHR and in the caselaw of the European Court, such as Diennet v France (1996) 21 EHRR 554.

29 [2010] NIQB 27, para. 27 (per Coghlin LJ). In reaching this conclusion the court drew upon recent pronouncements by the Supreme Court in In re Guardian News and Media Ltd [2010] 2 WLR 325, where Lord Rodger said (at para. 27) that "States are, of course, obliged by Articles 2 and 3 to have a structure of laws in place which will help to protect people from attacks on their lives ... Therefore, the power of a court to make an anonymity order to protect a witness or party from a threat of violence arising out of its proceedings can be seen as part of that structure. And in an appropriate case, where threats to life or safety are involved, the right of the press to freedom of expression obviously has to yield."

30 [2010] 2 WLR 325, para. 28 (per Lord Rodger).

31 [2009] NIQB 92.

32 Ibid. para. 27. Girvan LJ made reference to Re McCallion [2009] NICA 55, which looked specifically at the effect of such unincorporated treaty provisions.

33 (2005) 40 EHRR 12.

34 (1981) 3 EHRR 408.

35 [2009] NIQB 92, para. 28. 
at that court and that the decision there might well have implications for the conclusions he had reached. ${ }^{36}$

\section{The right to liberty}

In this field, five cases were decided. One was about the need for an oral hearing in a dispute about liberty, while the other four turned on whether there was a legal justification for the deprivation of liberty. Judgment in one other important case was still awaited at year's end.

The most significant judgment issued in relation to Article 5 was Re Reilly's Application, ${ }^{37}$ where a man serving a life sentence (imposed automatically under the Powers of Criminal Courts (Sentencing) Act 2000 because he had been convicted of a second serious offence) complained that the Parole Board of Northern Ireland had refused to give him an oral hearing when it was considering whether to release him on licence. After referring to relevant English and European precedents, Treacy J ruled that not every person applying to the Parole Board is entitled to an oral hearing, but he went on to hold that the case before him could be distinguished from the House of Lords' decision in $\mathrm{R}$ (West and Smith) v Parole Board $^{38}$ because there the prisoner was serving a determinate sentence whereas here he was serving an indeterminate one. This meant that what was at stake for the applicant when he applied to the Parole Board was more significant. Decisions by the ECtHR showed that an oral hearing would be required in most, if not all, cases involving indeterminate sentences, ${ }^{39}$ and the Parole Board could not argue that it would have made no difference to its decision if it had allowed the applicant an oral hearing because there was no way of knowing what impact new information might have had on its conclusions. Consequently, there had been a violation of Article 5(4) in this case, the provision that guarantees the right to a speedy court decision as to the lawfulness of a person's detention. There was an interesting followup a month later, when Treacy J ruled on what remedy Mr Reilly should be granted. The judge opted for an order of certiorari to quash the Parole Board's decision. He would not issue an order of mandamus because this would have had the effect of allowing Mr Reilly to jump the queue in the "serious backlog" of oral hearing cases. Nor was he prepared to award any compensation for the breach of Article 5(4), following two precedents of the English High Court. ${ }^{40}$ The case is a good illustration of what a hollow success winning an application for judicial review can be.

In a further case involving the revocation of a life prisoner's release on licence, $R e$ Knight's Application, ${ }^{41}$ the position of one of the most notorious murderers of the Northern Ireland troubles was under consideration. Knight had been convicted in 1995 of murdering 12 people. Having served just over five years of his life imprisonment he was released under the terms of the Northern Ireland (Sentences) Act 1998, which was enacted to implement part of the Belfast (Good Friday) Agreement. ${ }^{42}$ In 2009 he was convicted of disorderly behaviour and common assault on two sisters but before he was sentenced for those crimes his licence was suspended by the Secretary of State on the basis that he was a danger to the public and he was returned to prison. He argued that this was a breach of Article 5(1) of

36 The case is $A, B$ and $C$ v Ireland App. No 25579/05. It was heard by the Grand Chamber of the ECtHR on 9 December 2009. At the time of writing, judgment was expected before the end of 2010 .

37 [2010] NIQB 46.

38 [2005] 1 WLR 350.

39 Singh v UK (1996) 22 EHRR 1; Waite v UK (2003) 36 EHRR 54.

$40 \mathrm{R}(\mathrm{KB}) \mathrm{v}$ South London and South and West Region Mental Health Review Tribunal [2004] 1 QB 936; R (Degainis) v Secretary of State for Justice [2010] EWHC 137 (Admin).

41 [2010] NIQB 30.

42 Strand 3, section headed "Prisoners", esp. paras 1 and 4. 
the ECHR because there was no judicial authorisation for the detention. Treacy J rejected this argument, following the decision of the Court of Appeal of Northern Ireland in $\mathrm{R} e$ Mullan's Application. ${ }^{43}$ The applicant's return to prison was "in pursuance of his [original] sentence" as authorised by s. 9(3) of the 1998 Act. There was therefore no violation of Article 5(1). This was undoubtedly a decision on the lawfulness of the detention, to which the applicant was entitled under Article 5(4) of the ECHR, but his lawyers did not, unfortunately, raise any challenge based on the fact that more than four months had elapsed since the detention had begun and Article 5(4) requires a "speedy" decision from a court. While it is obvious that there was a legal justification for the detention, Knight should surely have had this confirmed by a court decision much sooner. As the law currently stands, it seems that in the context of recalls to prison the requirement for a "speedy" decision is applied very loosely in Northern Ireland.

Re Gerard O'Neill's Application ${ }^{44}$ required the High Court to decide if the transfer of a remand prisoner to police custody for questioning in relation to another offence had been conducted under the wrong piece of legislation and therefore constituted a breach of Article 5. The report indicates that it had not been entirely clear to the court why there were difficulties in using an alternative piece of legislation, but Weatherup J ruled that it did not make any difference which piece of legislation was used as far as Article 5 was concerned - each of them provided legal justification for the transfer. The point to bear in mind here is the important one that Article 5 requires states to adhere strictly to their own national laws on deprivation of liberty, even if those laws set standards that are higher than those on the face of the ECHR itself. If states do not do so, the European Court will rule that Article 5 has been violated. ${ }^{45}$

The Divisional Court had occasion to rely on Article 5 in two extradition cases, each involving Spain. In Juana Chaos v Kingdom of Spain, ${ }^{46}$ a suspected Basque terrorist had failed to comply with bail conditions imposed on him during extradition proceedings. The Spanish government sought a court order revoking the man's bail but, remarkably, there was no statutory provision expressly authorising such an order and the court was reluctant to imply authority from legislation or to say that it was part of the court's inherent jurisdiction. To do either of those things would have been to fall foul of Article 5 of the ECHR, which requires detention to be "in accordance with a procedure prescribed by law". An implied statutory power, or a power based on inherent jurisdiction, would lack the essential qualities of accessibility and foreseeability. ${ }^{47}$ The concept of "inherent jurisdiction" was described as "unpublished, undefined and unparticularised". The court went on to hold that there was statutory authority for the police to arrest the suspect for the offence of failing to surrender to custody while on bail, ${ }^{48}$ but the judges are nevertheless to be commended for disallowing revocation of bail and surrender of the suspect directly to the court without express statutory authority to support such actions. The decision is further evidence of the way in which Convention rights have become embedded in judicial reasoning in Northern Ireland, a phenomenon that in turn is partly due to references to the ECHR being embedded in the statute book. The Extradition Act 2003 imposes a specific duty on judges, before authorising a person's extradition, to ensure that it would be compatible with Convention

43 [2008] NI 258.

44 [2010] NIQB 8.

45 See, e.g., R White and C Ovey, The European Convention on Human Rights 5th edn (Oxford: OUP 2010), at p. 216.

46 [2010] NIQB 68.

47 Ibid. paras 25 and 27.

48 Criminal Justice (NI) Order 2003, article 5(1). The suspect subsequently went on the run: Belfast Telegraph, 20 April 2010. 
rights. ${ }^{49}$ The point also arose in the second Divisional Court case, Kingdom of Spain $\mathrm{v}$ Arteaga, ${ }^{50}$ where lawyers for the extraditee argued that he was being sought in connection with behaviour that was not criminal at the time it was committed, in breach of Article 7 of the ECHR. In the end the court approved the extraditee's discharge on the separate ground that there was a lack of specificity in the accusations being made against him. That too could be seen as a failure to meet the requirement to act "in accordance with a procedure prescribed by law".

Throughout the year observers eagerly awaited the judgment of the Divisional Court in Re Duffy's Application, where the issue is whether Part III of Schedule 8 to the Terrorism Act 2000 , which regulates the extension of detention periods for persons reasonably suspected of involvement in terrorism, is wholly compatible with Article 5 of the ECHR. ${ }^{51}$ This is obviously a very important question, not just from a human rights point of view but also a political one, as the length of permissible detention periods in terrorist cases has long been a subject of heated debate in UK parliamentary and media circles. The core conundrum is whether the grounds that Part III requires to be satisfied before an extension to detention can be granted are thorough enough to ensure that the procedure is "lawful" in light of the standards set by the ECtHR. Another provision in the Terrorism Act is also relevant, as it states that a detained person "shall be deemed to be in legal custody throughout the period of his detention". 52 On the face of it, this seems hard to reconcile with Article 5(4) of the Convention, which guarantees to a detainee the right to "take proceedings by which the lawfulness of his detention shall be decided speedily by a court and his release ordered if the detention is not lawful". It is not entirely satisfactory that the Divisional Court has taken so long to issue its final judgment in this case, given that the matter was heard by the court in September 2009. Ironically, during the course of the year the Court of Appeal had cause to upbraid a lower court for being slow to deliver a judgment (the delay was three-and-a-half years in that instance!). ${ }^{53}$ In doing so it cited the recent ruling by the ECtHR in Anderson v $U K,{ }^{54}$ which the Court of Appeal said "highlights the need for all courts to be vigilant to the need to manage their case load efficiently, not least at the decision making stage".

\section{The right to a fair trial}

Article 6 of the ECHR applies only in situations where a determination is being made of a person's civil rights and obligations or of a criminal charge against him or her. In 2009-10 there were four decisions on whether the applicant's "civil rights" had indeed been engaged, and a number of other decisions (both criminal and civil) on whether, given that Article 6 was engaged, its requirements had been violated.

Re JR 26's Application ${ }^{55}$ concerned a long-serving police officer who was transferred to other duties in the Police Service of Northern Ireland because his superiors had received

49 S. 21.

50 [2010] NIQB 23.

51 The Divisional Court has already held in the same case that a period of detention can be extended only if the judge deciding that matter also rules that the arrest of the detainee was lawful in the first place: [2009] NIQB 31. For further commentary, see B Dickson, "Article 5 of the ECHR and 28-day detention of terrorist suspects" (2009) 60 NILQ 231.

52 Sch. 8, Part I, para. 5.

53 Laverty v Dept of the Environment for Northern Ireland [2010] NICA 10, para. 11 (per Girvan LJ).

54 App. No 19859/04 (9 February 2010). The European Court found a violation of Article 6(1) because of delays in the Court of Session in dealing with the applicant's case against a commercial property company and Glasgow City Council alleging that statutory notices in respect of his property were invalid on grounds of fraud and illegal conspiracy.

55 [2009] NIQB 101. 
several intelligence reports that he was engaged in illegal drug activity. The main question was whether this was the kind of decision that was even amenable to judicial review, and Weatherup J held that it was not. He followed the test applied by the Court of Appeal of England and Wales in $\mathrm{R}$ (Tucker) v Director General of the National Crime Squad, ${ }^{56}$ which said that if a decision taken in relation to a police officer involved no disciplinary element then it was a purely operational decision, "a run of the mill management decision involving deployment of staff or the running of the force". 57 Article 6 was not therefore engaged. The judge added, obiter, that even if the decision in this case was justiciable there was no unfairness on the facts because the applicant had been supplied with the gist of the available information relied upon for the decision. In a subsequent case concerning a challenge to a decision by the Nursing and Midwifery Council to strike off a nurse for professional misconduct, the council accepted that the applicant's Article 6 rights were engaged and Treacy J endorsed that. ${ }^{58}$ But he went on to rule that the applicant had forfeited her Article 6 right to be present at the disciplinary hearing because she had in fact elected not to attend.

The Court of Appeal upheld another decision by Treacy $\mathrm{J}$ in relation to the nonapplicability of Article 6. The applicant was a woman whose UK passport had been withdrawn because it appeared that she was not, after all, entitled to British citizenship. ${ }^{59} \mathrm{It}$ seems that, if she had been entitled to citizenship, the withdrawal of her passport would have been judicially reviewable. But as the applicant admitted that she was not entitled to British citizenship - because she was not in fact the daughter of a British man - she could not be considered as being deprived of something she never had. ${ }^{60}$ The argument that she was a putative British citizen, and therefore entitled to have her Article 6 and 8 rights considered, was rejected. The view of Treacy J, in the court below, that Article 6 rights cannot be relied upon by someone who is denied entry into, or permission to stay within, a country, citing Maaoui v France, ${ }^{61}$ was impliedly approved.

Access to legal representation was at issue in $\mathrm{Re} A B$ 's Application, ${ }^{62}$ where a young man was requested to attend a disciplinary investigation meeting at his place of employment. He was allowed to be accompanied by an appropriate work colleague or an accredited trade union representative, but not by a legal representative. Treacy J held, in line with European and English authorities, 63 that Article 6 does not guarantee a right to such representation unless the applicant's right to practise his or her profession is at stake. The risk of losing a job is not itself sufficient to trigger the right in an employment context. The judge helpfully pointed out, however, that because the young man in this case was of limited intellectual capacity, his employers, a district council, might want to make a reasonable adjustment in his favour under the Disability Discrimination (NI) Order 2006. ${ }^{64}$

The exact moment at which Article 6 rights become available to someone who is suspected of a criminal offence, and the extent of the protection then granted, have been issues of some contention for many years. In Re Arthurs' Application they were explored in

56 [2003] EWCA Civ 57, [2003] ICR 599.

57 [2009] NIQB 101, para. 16.

58 Re Colton's Application [2010] NIQB 28, para. 28 and [2010] NIQB 42, paras 6 and 16.

59 Re Burnett's Application [2010] NICA 2.

60 The court relied on a decision by the Immigration Appeal Tribunal in England for this proposition: Christodoulidou v Secretary of State for the Home Dept [1985] Imm AR 179.

61 (2001) 33 EHRR 42.

62 [2010] NIQB 19.

63 Le Compte v Belgium (1982) 4 EHRR 1; Kulkarni $\mathrm{v}$ Milton Keynes Hospital NHS Foundation Trust [2009] EWCA Civ 689.

64 [2010] NIQB 19, para. 28. 
relation to a decision by the Director of Public Prosecutions (DPP) in Northern Ireland to proceed with the trial of two people charged with serious offences of dishonesty in the absence of a jury. ${ }^{65} \mathrm{He}$ did so under the Justice and Security (NI) Act 2007, which allows for trial without a jury if certain conditions have been met. ${ }^{66}$ These provisions replaced those governing the use of "Diplock Courts", which had been in place since 1973. Many had hoped that the peace process in Northern Ireland would have been far enough advanced by 2007 to allow for non-jury trials to be dispensed with altogether, but sadly that was not the case, given the level of residual "dissident" paramilitary activity in Northern Ireland. The 2007 Act differs from its predecessors in that it effectively establishes a presumption in favour of jury trial and requires the DPP to issue a certificate if he or she suspects that one or more of the conditions allowing for non-jury trial has been met. However, it then severely limits the grounds upon which such a certificate can be challenged. It allows for challenges only on the basis of "dishonesty, bad faith or other exceptional circumstances". ${ }^{67}$ The applicants in Re Arthurs' Application sought judicial review of a certificate, alleging that it was "substantively flawed, procedurally unfair and contrary to Article 6". ${ }^{68}$

The Divisional Court, in a judgment delivered by Girvan LJ, rejected the applicants' challenge, concluding that the wording of the legislation was clear and that a decision as to whether a defendant should be tried with or without a jury was not one that even engaged Article $6 .{ }^{69}$ It followed its own earlier decision in Re Shuker's Application. ${ }^{70}$ The court considered the apparently contrasting views expressed by Lord Judge LCJ in $R \mathrm{v} T,{ }^{71}$ where the Court of Appeal of England and Wales gave guidance on the proper approach to another statutory provision (also applicable in Northern Ireland) concerning the discharge of a jury when jury tampering has allegedly occurred. ${ }^{72}$ But the court in Belfast was able to reconcile its position with that guidance because in the case before it there was express statutory language requiring it to reject the challenge to the DPP's certificate. Later in the year Lord Judge very strongly reiterated his view that jury trial should be withdrawn only in extreme cases and as a last resort. ${ }^{73}$ But even he would have to admit that the wording of the 2007 Act in Northern Ireland is (unfortunately) sufficiently different from that of the 2003 Act as to require a less strict approach. The 2003 Act was considered in a further Northern Ireland case during the year, Re Clarke's Application, ${ }^{74}$ where McCloskey J meticulously analysed the provisions concerning jury-tampering. ${ }^{75}$ On the facts (which concerned a so-called "tiger-kidnapping") 76 the judge was satisfied that tampering had indeed occurred and that there would be no unfairness to either defendant in continuing the

$65[2010]$ NIQB 75.

66 Ss. 1-9.

67 S. 7. When first presented to Parliament this provision had been worded in an even more draconian way (freeing it from having to comply with the Human Rights Act!), but it was amended after protests from, amongst others, Parliament's Joint Committee on Human Rights and the House of Lords' Select Committee on the Constitution.

[2010] NIQB 75, para. 19.

69 Ibid. para. 29.

70 [2004] NI 367.

71 [2009] 3 All ER 1002.

72 Criminal Justice Act 2003, s. 7.

73 R v KS [2010] EWCA Crim 1756; R v J, S and $M$ [2010] EWCA Crim 1755.

74 [2010] NICC 7. The Court of Appeal later dismissed an appeal from this decision (unreported).

75 In particular, s. 46(3).

76 Where one or more persons is held captive while a family member or friend is forced to assist the criminals in committing a crime. 
trial without a jury. Like the court in Re Arthurs' Application, he drew upon the words of Lord Judge LCJ in $\mathrm{R} v \mathrm{~T}^{77}$ (while reminding us that decisions of the Court of Appeal in England and Wales are only persuasive, not binding, authorities in Northern Ireland). ${ }^{78}$ Lord Judge had intimated that a judge should usually continue the trial without the jury rather than terminating it and allowing a retrial to occur. ${ }^{79}$ This was because there would be huge inconvenience and expense involved in a retrial and a continuation of the trial would reduce any possible advantage accruing to those responsible for jury tampering. Later in the year, McCloskey J convicted the two defendants in this case, drawing adverse inferences from their silence on certain matters; ${ }^{80}$ he did so after noting that this too was not incompatible with the ECHR. ${ }^{81}$

In $\mathrm{R} v$ McAnespie, ${ }^{82}$ Coghlin LJ declared admissible statements made by witnesses who were too frightened to give evidence in person. In doing so he preferred to follow a persuasive authority of the Court of Appeal of England and Wales ${ }^{83}$ rather than what appeared to be a conflicting decision by the ECtHR in Khawaja v United Kingdom. ${ }^{84}$ This was the legally correct way to proceed (as already noted), ${ }^{85}$ and it also proved prophetic, for when the Supreme Court later decided $R$ v Horncastle it enthusiastically endorsed the Court of Appeal's position and went out of its way to include an annex to the judgments ${ }^{86}$ that was intended to inform the Grand Chamber of the ECtHR (to which Al-Khawaja had meanwhile been referred) of how English common law was not, in the eyes of senior UK judges, incompatible with the Convention in this field. ${ }^{87}$

In recent years several convictions dating from the 1970s to 1990s in Northern Ireland have been quashed by the Court of Appeal on the basis that, in the light of evidence about police brutality, or failure to tell the truth, or failure to allow legal advice to be made available to suspects during police interrogations, the convictions were unsafe. A notable success during the past year was the appeal brought by Christopher Walsh, who in 1992 had been sentenced to 14 years' imprisonment for possession of a coffee jar bomb. ${ }^{88} \mathrm{He}$ had twice before lost an appeal in the Court of Appeal. But it is clear that not all victims of these miscarriages of justice are entitled to compensation. In Re MacDermott's Application, 89 the Court of Appeal confirmed its own previous ruling ${ }^{90}$ that under the relevant statutory

\footnotetext{
77 [2009] 3 All ER 1002.

78 [2010] NICC 7, para. 20.

79 [2009] 3 All ER 1002, para. 20.

80 [2010] NICC 13.
}

81 Ibid. para. 53, citing Averill v UK (2001) 31 EHRR 36. The same judge reassured himself that he was not acting incompatibly with the ECHR in a case concerning the admissibility of bad character evidence (and when sentencing the accused for murder): R v Cruickshank and McEleney [2010] NICC 69 and 78. Coghlin LJ did likewise in a case where two men were prosecuted in 2007 for a murder carried out in 1981: R v Mc Anespie [2009] NICC 61. See also (on the same point about sentencing for murder) R v Meehan [2010] NICC 59, para. 16 (per McCloskey J).

82 [2009] NICC 62.

83 R v Horncastle [2009] EWCA Crim 964.

84 (2009) 49 EHRR 1.

85 See the text at n. 8 above.

86 Annex 4 (compiled by Lord Judge LCJ). It runs to 96 paras.

87 R v Horncastle [2010] 2 WLR 47.

88 [2010] NICA 7.

89 [2010] NICA 3.

90 In Re Boyle's Application [2008] NICA 35. 
provision, ${ }^{91}$ which was intended to give effect to a requirement of the UN's ICCPR, ${ }^{92}$ compensation was payable only to people who could demonstrate that they were innocent or that they should not have been convicted. ${ }^{33}$ The latter category does not include people who can only demonstrate that they might not have been convicted. Such people are left to their remedies under the law of tort, but of course such remedies are extremely difficult to obtain so long after the events have occurred. The case for an ex gratia payment on the part of the state is surely very strong in such cases. ${ }^{94}$

There was a reminder during the year, in Quinn v McAleenan, ${ }^{95}$ that Article 6 is not incompatible with the grant of a civil judgment in default of defence. The consideration of this matter (on appeal from a District Judge in a county court) was conducted on the papers alone, without a hearing. As this appellate procedure was adopted with the consent of the parties,${ }^{96}$ it too was ruled not to be incompatible with Article 6. ${ }^{97}$

\section{The right to a private and family life}

In recent years, the rights protected by Article 8 of the Convention have been interpreted widely by the ECtHR. ${ }^{98}$ This is reflected in the very differing contexts in which Article 8 challenges arose in Northern Ireland's courts during 2009-10. They ranged from environmental planning, through misuse of private information, to family relationships and the treatment of prisoners.

Re Boswell's Application ${ }^{99}$ was concerned with a judicial review of a refusal to grant planning permission within a green belt area to an Irish traveller family. The applicant argued that the Planning Appeals Commission had failed to properly consider the evidence that there was no alternative available to the family other than the proposed site and that it had not given special consideration to the specific needs and vulnerability of travellers. Weatherup $\mathrm{J}$ noted, in accordance with Chapman $\mathrm{v} U K,{ }^{100}$ that states have a positive obligation to "facilitate the Gypsy way of life",101 but he found that the planning framework in Northern Ireland did provide for special consideration of traveller needs and their different lifestyles. ${ }^{102}$ However, he also found that the suitability of alternative accommodation had not been taken into account and so the positive obligation had not been fully discharged. ${ }^{103}$ That aspect was remitted to the Commission for reconsideration.

91 Criminal Justice Act 1988, s. 133. The right to compensation for a wrongful conviction is set out in Article 3 of Protocol 7 to the European Convention, but the UK (unlike Ireland) has not ratified that Protocol.

92 Article 14(6).

93 [2010] NICA 3, para. 12. In the leading House of Lords' authority on this point, R (Mullen) v Secretary of State for the Home Dept [2004] UKHL 18, [2005] 1 AC 1, Lord Steyn would have restricted compensation to people who could show that they were clearly innocent.

94 See the then Home Secretary's statement to Parliament in 1985 (HC Debs, 29 November, vol. 87, cols 691-2), discussed by the House of Lords in In re McFarland [2004] UKHL 17, [2004] NI 380.

95 [2010] NIQB 31.

96 [2010] NIQB 31, para. 2 (per Gillen J), following Kerr v Ulsterbus Ltd [2010] NIQB 2.

97 In Re McCafferty's Application [2009] NICA 59, the Court of Appeal rejected the argument that a decision to revoke a convicted person's release on licence could not be taken by a minister who also had responsibility for security: he could not be considered a biased individual either under the common law or under Article 6.

98 D Harris, M O'Boyle, E Bates and C Buckley, Law of the European Convention on Human Rights 2nd edn (Oxford: OUP 2009), pp. 363-81.

99 [2009] NIQB 95.

100 (2001) 33 EHRR 18.

101 Ibid. para. 96.

102 [2009] NIQB 95, para. 18.

103 Ibid. para. 26. 
In Ewing v Times Newspapers Ltd, ${ }^{104}$ the High Court had to consider Article 8 within the developing parameters of the newly titled tort of "misuse of private information". 105 The claimant had issued proceedings alleging that the defendant had breached his right to privacy or confidentiality by publishing a number of items of personal information. The defendant made an application to have the claim struck out on the grounds that it did not reveal any reasonable cause of action. After examining some of the recent English authorities pertaining to Article 8 and privacy, such as Campbellv MGN Ltd 106 and McKennitt $\mathrm{v} A$ sh, ${ }^{107}$ Coghlin LJ confirmed that the first limb of the newly formed tort was to identify whether the subject in question had an objectively reasonable expectation of privacy in relation to information or material that was central to the proceedings. Coghlin LJ then ruled, again in line with English authorities, ${ }^{108}$ that if there was a reasonable expectation of privacy one had to balance "the claimant's interest in keeping the information private against the countervailing interests of the recipient in publishing it", 109 in other words the recipient's Article 10 rights. ${ }^{110}$ On the facts of this case, Coghlin LJ was not persuaded that the claimant had any realistic prospect of demonstrating a reasonable expectation of privacy in respect of any of the pertinent information, because the information in question was either of a trivial nature or already in the public domain. ${ }^{111}$ Even if he was wrong in this, he held that, as the information related to wrongdoing, "no reasonable court approaching the balancing exercise in a proportionate a manner could do other than give precedence to the defendant's Article 10 rights". ${ }^{112}$ The claim was therefore struck out.

The tort of misuse of private information was also discussed in McGaughey $\mathrm{v}$ Sunday Newspapers $L t d,{ }^{113}$ during the course of which McCloskey J clarified that the purpose of damages in privacy proceedings is to provide the plaintiff with "fair and reasonable compensation for any proven injury to his feelings and mental distress". 114 This is a significant pronouncement, as there had previously been much discussion about the nature of damages in privacy actions. 115

The High Court had cause to revisit Article 8 in Re Success's Application, ${ }^{116}$ a challenge by way of judicial review to a decision of the UK Border Agency. The agency had rejected an application to revoke both a deportation order and a later certificate, ${ }^{117}$ saying that

104 [2010] NIQB 7.

105 Campbell v MGN Ltd [2004] 2 AC 457, at para. 51 (per Lord Hoffmann).

106 [2004] 2 AC 457.

107 [2005] EWHC 3003.

108 The judge made specific reference to Buxton LJ in McKennitt v Ash, ibid. para. 11. See too Max Mosley v News Group Newspapers Ltd [2008] EWHC 1777 and David Murray v Express Newspapers plc and Big Pictures (UK) Ltd [2008] 3 WLR 1360 (CA).

109 [2010] NIQB 7, para. 19.

110 In $\operatorname{Re} S$ (A Child) (Identification: Restrictions on Publication) [2005] 1 AC 593, para. 11, Lord Steyn indicated that there are four stages to any balancing act between Articles 8 and 10. He stated that those stages are "first, neither article has as such precedence over the other. Secondly, where the values under the two articles are in conflict, an intense focus on the comparative importance of the specific rights being claimed in the individual case is necessary. Thirdly, the justifications for interfering with or restricting each right must be taken into account. Finally, the proportionality test must be applied to each."

111 [2010] NIQB 7, para. 28.

112 Ibid. para. 30.

113 [2010] NICh 7.

114 Ibid. para. 16.

115 See, e.g., the judgment of Eady J in Max Mosley v News Group Newspapers Ltd [2008] EWHC 1777, paras 185-97 and 212-31.

116 [2010] NIQB 35.

117 Issued under the Nationality Immigration and Asylum Act 2002, s. 96(1). 
matters raised by the applicant in relation to his Article 8 right to a family life could have been raised on a first appeal from a former decision but were not. Weatherup $J$ found that the immigration judge and the review judge had not taken into account the continuing family relationship between the applicant, his partner and their child. He therefore ruled that "the ongoing relationship with the applicant's partner was not decided upon under the old decision". 118 This meant that he could set the certificate aside. He also made some obiter comments regarding the application of Article 8 within the context of deportation, noting that contact proceedings "may provide a ground for consideration of the right to family life under Article 8 as removal from the jurisdiction could interfere with the ability to advance the contact claim". ${ }^{119}$ This illustrates the multifaceted nature of Article 8 rights in deportation proceedings and highlights the overlap with access to court rights under Article 6. ${ }^{120}$

Article 8 was also referred to several times in family proceedings. In Re L (Removal from the Jurisdiction - Holiday), ${ }^{121}$ Stephens J was faced with an application to remove children who were subject to a residence order ${ }^{122}$ from the jurisdiction for the purposes of a holiday. The judge noted that the application engaged all of the actors' Article 8 rights and so in reaching his conclusions he had specific regard to those. In $G$ and $D$ (Risk of forced marriage: Forced marriage protection order $)^{123}$ the High Court was asked to make a forced marriage protection order under the Forced Marriage (Civil Protection) Act 2007. ${ }^{124}$ It is obvious that such an order has the potential to have a detrimental impact on a number of persons' Article 8 rights. Stephens J therefore indicated that any proposed order would need to be justified in accordance with the requirements of Article 8(2). On the facts he held that an order was a proportionate response. In $M c K$ v $M c K,{ }^{125}$ Master Redpath applied $R$ v Qureshi ${ }^{126}$ when holding that, when an assets recovery order is made against one spouse, the Article 8 rights of the other spouse are not abrogated and so have to be given express consideration before any further order is made.

In a further family law case, arguments based on the EU's Charter of Fundamental Rights, rather than the ECHR, were raised. Re Jakub and Dawid ${ }^{27}$ was an appeal by the mother of two children against the registration and enforcement of an order made by a Polish court granting residence rights to her husband, the father of the children. The mother contended that the views of the children, who did not wish to go to Poland, should be taken into account in accordance with their age and maturity, relying on Article 24(1) of the

118 [2009] NIQB 35, para. 17.

119 Ibid. para. 9.

120 Arguably Weatherup J's observations about the applicant's ability to advance a contact claim are representative of the growing importance of the right of access to a court. In recent years, this right has attained the status of a "constitutional right" and the courts have attached more significance to it. See R Clayton and H Tomlinson, Fair Trial Rights (Oxford: OUP 2009), paras 11.44-122.

121 [2009] NIFam 21.

122 Under the Children (NI) Order 1995, article 8. Article 13 provides that, when a child is subject to a residence order, he or she must not be removed from the jurisdiction unless the person wishing to remove the child has obtained either the consent of all those who are endowed with parental responsibility or leave of the court.

123 [2010] NIFam 6.

124 Sch. 1, Part 1.

125 [2009] NIMaster 76.

126 [2005] 1 WLR 122.

127 [2009] NIFam 23. 
Charter ${ }^{128}$ and the Preamble to "Brussels II Revised", 129 both of which provide protection to the rights of the child. On the facts, Stephens J felt that the order of the Polish court was in the best interests of the children, and in reaching that conclusion he took their views into account. ${ }^{130}$ Even though the United Kingdom negotiated an opt-out from the enforceability of the EU Charter in domestic courts, through a Protocol to the Treaty of Lisbon in 2009, the exact import of that opt-out has still to be clarified by the courts. ${ }^{131}$

Article 8 issues were also raised in several cases involving prisoners. In Re Craig's Application, ${ }^{132}$ the applicant sought judicial review of a Prison Service policy on the passing of money to and from prisoners. ${ }^{133} \mathrm{He}$ argued that his Article 8 rights were being unlawfully and disproportionately interfered with in that he was being prevented from passing on to his daughter money he had earned in prison. ${ }^{134}$ But Stephens J held that the policy and the decisions based on it did have an adequate legal foundation ${ }^{135}$ and on the proportionality point he accepted that the Prison Service had "carefully balanced the considerations that lie at the heart of the policy". ${ }^{136}$ He highlighted recent comments by Northern Ireland's Lord Chief Justice, Sir Declan Morgan, in Re Phillips' Application, where he indicated that a considerable degree of weight should be given to the evaluations of the Prison Service in light of their "particular insights" into prison issues. ${ }^{137}$ The judge also dismissed the applicant's argument based on the European Prison Rules by holding that the "spirit and intent" of the rules had informed the Article 8 duty on the respondent during the formulation and promulgation of the policy and also during the making of the governor's decisions. ${ }^{138}$ The governor had taken into account the availability of other schemes that allowed the applicant to provide for his daughter.

In Re Barron's Application, ${ }^{139}$ the applicant sought leave to judicially review both the policy and the decisions of the Prison Service in relation to strip searches. It was alleged, amongst other things, that the policies and practices violated the applicant's rights under Articles 3 and 8. But Treacy J refused leave on the ground that the matter was more suitably disposed of in tort proceedings. ${ }^{140}$ In Re Mc Aree's and Watson's Application, ${ }^{141}$ the applicants challenged the Prison Service's decision to transfer them to the Harm Reduction Unit

128 "Children shall have the right to such protection and care as is necessary for their well-being. They may express their views freely. Such views shall be taken into consideration on matters which concern them in accordance with their age and maturity."

129 This is actually Council Regulation (EC) No 2201/2003 (27 November 2003). Para. 33 of its Preamble states: "This Regulation recognises the fundamental rights and observes the principles of the Charter of Fundamental Rights of the European Union. In particular, it seeks to ensure respect for the fundamental rights of the child as set out in Article 24 of the Charter of Fundamental Rights of the European Union."

130 [2009] NIFam 23, para. 45.

131 See R (Saeedi) v Secretary of State for the Home Dept [2010] EWHC 705 (Admin), which the Court of Appeal has since referred to Luxembourg for a preliminary ruling from the European Court of Justice.

132 [2009] NIQB 45.

133 The policy is contained in a Prison Service document entitled "Inmate's personal cash accounts".

134 The applicant also sought to rely on Article 1 of Protocol 1. However, the parties accepted that, in light of the conclusions of the House of Lords in Belfast City Council v Miss Behavin' Ltd [2007] 1 WLR 1420, the arguments based on this provision added nothing to the challenge based on Article 8.

135 Namely, the Prisons and Young Offenders Centre Rules (NI) 1995, r. 18.

136 [2010] NIQB 45, para. 32.

137 [2009] NIQB 64, para. 13.

138 [2010] NIQB 45, para. 35.

139 [2010] NIQB 21.

140 In which case the ECtHR's decision in Wainwright v UK (2007) 44 EHRR 809 will no doubt be relied upon.

141 [2010] NIQB 79. 
(HRU) of Magilligan Prison. Both relied on Article 6 (and largely succeeded on that ground because of the lack of information they had been given about the grounds for their transfer) but the first applicant also cited Article 8, Article 9 and Article 2 of Protocol 1 (the right to education). Treacy J found no breach of Article 8 or of Article 2 of Protocol 1, and as regards Article 9 he held that the applicant had been placed in the HRU for the legitimate purpose of maintaining order and discipline within the prison.

In Re Maguire's Application, ${ }^{142}$ a decision of the Prison Service not to give assurances to the applicant that he would not be subjected to covert surveillance during his prison visits was judicially reviewed. The applicant also sought a declaration that a statutory code of conduct and a prison rule were incompatible with Article $8 .{ }^{143} \mathrm{He}$ argued that the code did not contain the minimum safeguards required by the ECHR, being neither "in accordance with the law" nor "necessary". The issues were not directly addressed in this initial judgment, which focused on confirming that the High Court, rather the Investigatory Powers Tribunal, had jurisdiction to hear the matter. The Article 8 arguments will doubtless be aired more fully in later proceedings.

The applicants in Re McNamee and McDonnell ${ }^{14}$ were a firm of solicitors who sought to question a decision by the police not to allow an arrested person, who had been detained on suspicion of fraud and money laundering, access to a solicitor from the applicants' firm. This decision had been made as a result of the belief that a conflict of interest might arise because of the firm's involvement with the arrested person's transactions. McCloskey J granted leave to pursue a judicial review on the basis that Article 8 and Article 1 of Protocol 1 of the ECHR may have been breached.

Probably the oddest case raising Article 8 during the year was Re Carter's Application, ${ }^{145}$ where Treacy J refused leave to judicially review the Smoking (NI) Order 2006. The applicant had argued that the order and his conviction under it were incompatible with his rights under Articles 3, 8 and 14, but the judge, citing the English Court of Appeal in $R(G)$ v Nottingham Health Care Trust, ${ }^{146}$ noted that there was "no unfettered right to smoke provided by the Convention". The "limited prohibition" placed on the applicant did not violate any of his Convention rights. ${ }^{147}$

\section{The right to freedom of expression}

Both privacy and libel proceedings raised Article 10 issues during the year, as already indicated in the discussion of Ewing $\mathrm{v}$ Times Newspapers Ltd. ${ }^{148}$ In the high-profile libel action of Allister v Paisley, ${ }^{149}$ which involved two well-known local politicians, Gillen J was faced with an application for an interlocutory injunction aimed at restraining both publication and distribution of allegedly defamatory statements contained in an election leaflet. The judge observed that it has long been recognised that such injunctions should be granted only in exceptional circumstances, ${ }^{150}$ a reflection of the importance attached to the

142 [2010] NIQB 18 (Treacy J).

143 The code was issued under the Regulation of Investigatory Powers Act 2000, s. 71; the rule was the Prisons and Young Offenders Centre Rules (NI) 1995, r. 67(8).

144 [2010] NIQB 29.

145 [2010] NIQB 69.

146 [2008] HRLR 42.

147 [2010] NIQB 69, para. 13.

148 See the text at n. 104 above.

149 [2010] NIQB 48.

150 See Coulson v Coulson (1887) 3 TLR 846 and Bonnard v Perryman (1891) 2 Ch 269. 
right of free speech by the common law, now underpinned by Article $10 .{ }^{151}$ Gillen $\mathrm{J}$ then moved to examine the procedural requirements imposed by s. 12 of the Human Rights Act 1998, which provides, amongst other things, that "no such relief is to be granted so as to restrain publication before trial unless the court is satisfied that the applicant is likely to establish that publication should not be allowed". ${ }^{152}$ This provision had been interpreted by the House of Lords in Cream Holdings Ltd v Banerjee, ${ }^{153}$ where it was held that courts will "be exceedingly slow to make interim restraint orders where the applicant has not satisfied the court he will probably (more likely than not) succeed at trial". ${ }^{154}$ In applying this approach Gillen J stated that "the importance of leaving free speech unfettered is a strong reason in cases of libel for dealing most cautiously and warily with the granting of interim injunctions". ${ }^{155} \mathrm{He}$ added that this was particularly true in cases involving political speech at times of an election. ${ }^{156}$ With this in mind, the judge found that, as it had not been proven that the statements were defamatory or that there were no defences open to the defendants, this was not an exceptional case warranting the granting of an interlocutory injunction.

In McDonnell ( $t /$ a Microclean Environmental) $\mathrm{v}$ Adair, ${ }^{157}$ the plaintiff was appealing against an order of a Master striking out his libel claim on the grounds of abuse of process. In denying relief McCloskey J relied heavily on the English Court of Appeal's decision in Jameel v Dow Jones \& Co Inc., 158 where Lord Phillips MR asserted that, as public authorities, courts were under a statutory duty 159 "to administer the law in a manner which is compatible with Convention rights, in so far as it is possible to do so", ${ }^{160}$ and where he added that, in defamation proceedings:

keeping a proper balance between the Article 10 right of freedom of expression and the protection of individual reputation must ... require the court to bring to a stop as an abuse of process defamation proceedings that are not serving the legitimate purpose of protecting the claimant's reputation, which includes compensating the claimant only if that reputation has been unlawfully damaged. ${ }^{161}$

Not to stop the proceedings could constitute an unnecessary interference with freedom of expression. ${ }^{162}$ Dismissing a libel action on this basis does not constitute a breach of the plaintiff's Article 6 rights, because Article 6 does not require "the provision of a fair and public hearing in relation to an alleged infringement of rights when the alleged infringement is shown not to be real or substantial". ${ }^{163}$ Applying this test, McCloskey J held that the facts before him did "not give rise to a real and substantial tort". 164 There had only been limited

151 [2010] NIQB 48, paras 15-16.

152 S. $12(3)$.

153 [2005] 1 AC 253.

154 Ibid. para. 22 (per Lord Nicholls). The House of Lords also said that this approach was to be applied pragmatically: depending on the factual matrix of the case at hand "it may be necessary for the court to depart from this general approach and a lesser degree of likelihood will suffice” (ibid.). For an example of the application of the House's reasoning see Jobn v Associated Newspapers Ltd [2006] EMLR 27.

155 [2010] NIQB 48, para. 23.

156 In this respect the judge cited the case of Bowman $\mathrm{v}$ UK (1998) 26 EHRR 1.

157 [2009] NIQB 93.

158 [2005] QB 946.

159 Imposed by the Human Rights Act 1998, s. 6.

160 [2005] QB 946, para. 55.

161 Ibid.

162 Ibid. para. 40.

163 Ibid. para. 71.

164 [2009] NIQB 93, para. 28. 
publication and what publication there had been had not made the recipients think less of the plaintiff.

\section{The prohibition of discrimination}

As is to be expected, claims of discrimination tended to arise as adjuncts to claims that other Convention rights had been violated. Those other rights were the right to property, the right to liberty and the right to a fair trial. ${ }^{165}$

The most prominent Article 14 judgment of the year was undoubtedly Re Morrison's Application, ${ }^{166}$ which concerned a challenge to the lawfulness of the Police Service and Police Service of Northern Ireland Reserve (Injury Benefit) Regulations 2006. These sought to limit eligibility for benefits to "a surviving spouse or surviving civil partner of a police officer who dies or has died as a result of an injury . . . in the execution of duty". ${ }^{167}$ The applicant, whose partner had been killed during the execution of his duty, challenged the regulations on the ground that they discriminated against her as an unmarried partner, in violation of Article 14 taken in conjunction with Article 1 of Protocol 1. In finding for the applicant, Treacy J embarked upon a detailed examination of the recent European and domestic case law pertaining to Article 14 . He readily accepted that authorities showed that the claim was within the "ambit" of Article 1 of Protocol 1, 168 notwithstanding that the benefits in question did not arise under a contributory scheme. ${ }^{169}$

The judge then held, following a recent decision by the House of Lords in an appeal from Northern Ireland, ${ }^{170}$ that being unmarried could be a "status" for the purposes of Article 14. On whether there was a valid comparator he acknowledged that there have been instances when the ECtHR has dismissed applications because the applicant was unable to identify a suitable comparator, ${ }^{171}$ but he said those cases had to be viewed in light of the recent comments of Baroness Hale in AL (Serbia) v Secretary of State for the Home Department to the effect that it was rare for the ECtHR to find that the chosen comparator was not in a relevantly analogous position. ${ }^{172}$ Baroness Hale had approved an approach that glosses over the comparability test and focuses instead on the justification test, that is, on whether the reasons for the difference in treatment amount to an objective and reasonable justification. ${ }^{173}$ Treacy J agreed with this approach and, on the facts, held that the difference in treatment here was not capable of being justified. ${ }^{174}$ This case reflects the move from formal to substantive equality that has been evident in many recent judgments of the

165 This article does not summarise developments in discrimination law in Northern Ireland's industrial and fair employment tribunals during 2009-10.

166 [2010] NIQB 51.

167 Regs 12(1) and 13(1).

168 Article 14 is not a free-standing equality guarantee. Rather, for Article 14 to be engaged, the issue in question must fall within the "ambit" of one of the other Convention rights (EB v France (2008) 47 EHRR 21), although this does not mean that that particular right must have been violated. For a discussion of the operation of Article 14, see S Livingstone, "Article 14 and the prevention of discrimination in the European Convention on Human Rights" [1997] EHRLR 25.

169 He cited Stec v UK (2006) 43 EHRR 47 and R (RJM) v Secretary of State for Work and Pensions [2009] 1 AC 311.

$170 \operatorname{Re}$ G (Adoption: Unmarried Couple) [2008] UKHL 38, [2009] 1 AC 173.

171 The judge identified Shackell v UK App. No 45851/99 (27 April 2000) and Burden and Burden v UK (2008) 47 EHRR 38 as such cases. The concept has also been used in Carson v UK (2009) 48 EHRR 41; see n. 186 below.

172 [2008] 1 WLR 1434, para. 25.

173 Ibid.

174 [2010] NIQB 51, paras 36 and 53. 
ECtHR and the House of Lords/Supreme Court. ${ }^{175}$ A growing emphasis has been placed on the justification or proportionality stage of an Article 14 inquiry rather than on prior issues such as the "ambit" of the other Convention article involved. The courts are thereby applying a more "piercing standard" of equality. ${ }^{176}$

The position adopted in Re Morrison's Application contrasts sharply with that preferred in Re McIlwaine's Application, ${ }^{177}$ which concerned a claim that a prisoner's release date had been miscalculated. The Divisional Court held that it had not, applying its own decision in an earlier case in which double counting of remand time had been prohibited when a person was being sentenced for two different offences. ${ }^{178}$ Unfortunately, the court rather summarily dismissed the applicant's additional claim that he had been improperly discriminated against under Article 14 of the ECHR. He argued that if he had not already been in prison when he was remanded in custody for a subsequent offence he would have had the full benefit of that remand period when sentenced for that offence. The report of the case does not explain why this difference in treatment is not a sufficient difference for the purposes of Article 14. The court merely stated that, as it did not consider that Article 5 , or indeed Articles 7 or 8 , were even engaged in the case, it did not propose to give further consideration to Article 14. With respect, this seems a cursorily dismissive approach. There was surely a plausible argument that this prisoner had been deprived of his liberty in a discriminatory way. Even if Article 5 had not itself been violated, this did not mean that there had been no violation of Article 14. The court should have explored in more detail whether the prisoner had a different "status" from that of a prisoner who had been released after the earlier sentence.

A further claim alleging a breach of the right to a fair trial fell at the first hurdle in $R e$ Mac Giolla Cathain's Application, ${ }^{179}$ where the Court of Appeal ruled that the applicant, who was a member of a band that wanted to play at a cultural centre, which was applying for an occasional liquor licence, had no standing to challenge the Administration of Justice (Language) Act (Ireland) 1737. That Act requires proceedings for such a licence (and all other court proceedings) to be held in English and no other language, such as Irish. Even if the applicant had had standing and could argue that his Article 6 rights were engaged, ${ }^{180}$ the court found that the difference in treatment between English speakers and non-English speakers was in this matter "manifestly necessary and proportionate". ${ }^{181}$ This must be right, and any change in policy on this matter must surely be left to the legislature. Controversially, the court observed that the 1737 Act was not originally designed as an anti-Irish law but as a pro-litigant law, because it prevented people from being misled by court documents written in Latin, French or other foreign languages. ${ }^{182}$

The conjunction of Article 6 with Article 14 was further considered in a case where leave was sought to apply for judicial review of a decision by the Legal Services

175 For a more in-depth discussion of the move towards substantive equality, see R O'Connell, "Cinderella comes to the ball: Article 14 and the right to non-discrimination in the ECHR" (2006) 29 Legal Studies 211.

176 Sandra Fredman, Discrimination Law (Oxford: Clarendon Press 2002), p. 88.

177 [2009] NIQB 91.

178 Re McAfee's Application [2008] NIQB 142.

179 [2010] NICA 24.

180 It was on the latter point that in the court below Treacy J had held against the applicant: [2009] NIQB 66, para. 44. He also ruled that the applicant could not rely upon Article 7(2) of the European Charter for Regional or Minorities Languages because, although the Charter had been ratified by the UK, it had not been incorporated into domestic law.

181 [2010] NICA 24, para. 8.

182 Ibid. para. 9. 
Commission to refuse free legal aid to a woman who was to be interviewed by social security officers in relation to alleged benefit fraud. ${ }^{183}$ She argued that it was discriminatory for her not to be entitled to free legal aid, given that someone being interviewed by a police officer in connection with a serious offence would have been so entitled. ${ }^{184}$ But Weatherup J held that, even assuming Article 6 was engaged on these facts, the difference in treatment was not based on a "status", as required by Article 14. As the ECtHR put it in Beale v UK, ${ }^{185}$ the different treatment arose not in relation to a personal characteristic but to the applicant's circumstances, which was not enough. This is a fine line to draw, and its positioning can divide very senior judges, as is clear from recent litigation involving the non-payment of pension upgrades to some pensioners living outside the United Kingdom. ${ }^{186}$

\section{Conclusion}

In 2009-10 the judges in Northern Ireland considered Convention rights in a wide variety of contexts and took full account of relevant Strasbourg caselaw. They continued to develop a corpus of home-grown precedents and to make use of English precedents when available. Occasionally, the exploration of Convention points might have been more thorough, but whether this was due to a failure by counsel to present appropriate arguments or to too summary an approach by the judges when composing their judgments is hard to say. Difficult issues around the protection of human rights will continue to come before the courts, thereby realising one of the central aims of the Human Rights Act 1998 - the development of a rights-based culture within the legal professions and the judiciary. That culture is further evidenced by the increasing number of references to other international human rights treaties such as the ICCPR and the EU's Charter of Fundamental Rights, even if the judges are still reluctant to apply such standards unless they have been formally incorporated into domestic legislation. There continues to be scope for further judicial activism in developing the common law in a way which brings it more into line with the UK's human rights obligations at the international level.

183 Re Stokes' Application [2009] NIQB 102.

184 Under the Legal Advice and Assistance Regs (NI) 1981, reg. 7A.

185 App. No 16743/03 (12 October 2004). Here, the court declared inadmissible a claim by an applicant convicted of mistreating sheep, because he had chosen not to be legally represented at interviews conducted with him by local trading standards officers.

186 In R (Carson) v Secretary of State for Work and Pensions [2006] 1 AC 173, the House of Lords held by 4:1 that this did not amount to a violation of Article 14 (taken in conjunction with Article 1 of Protocol 1). A Chamber of the European Court agreed by 6:1 (2009) 48 EHRR 41 and the Grand Chamber also agreed, but only by 11:6 (2010) 51 EHRR 13. 
